\title{
GEOLOGY AND ORE MINERALISATION OF NEOGENE SEDIMENTARY ROCK HOSTED LS EPITHERMAL GOLD DEPOSIT AT PANINGKABAN, BANYUMAS REGENCY, CENTRAL JAVA, INDONESIA
}

\author{
Arifudin Idrus ${ }^{* 1}$, Fahmi Hakim ${ }^{1}$, I Wayan Warmada ${ }^{1}$, Mochammad Aziz ${ }^{2}$, Jochen Kolb ${ }^{3}$, \\ and F. Michael Meyer ${ }^{4}$ \\ ${ }^{1}$ Department of Geological Engineering, Gadjah Mada University, Yogyakarta, Indonesia \\ ${ }^{2}$ Department of Geological Engineering, Jenderal Soedirman University, Indonesia \\ ${ }^{3}$ Geological Survey of Denmark \& Greenland \\ ${ }^{4}$ RWTH Aachen University, Germany
}

\begin{abstract}
Low suphidation (LS) epithermal gold deposits were recently found in the Paningkaban area, Central Java province, Indonesia, with more than five hundred artisanal gold miners currently operating in the area. This study is aimed to understand the geological factors controlling the gold mineralization and to characterize the alteration and ore mineralogy of the deposit. Several epithermal veins/veinlets trending $N-S, N W-S E$, and NE-SW are hosted by Tertiary turbiditic volcanoclastic sedimentary rocks of the Halang formation. This formation is composed of looping gradation of sandstone and siltstone units. Pre- and syn-mineralization structures such as extension joints, normal sinitral fault and sinitral fault control the gold mineralization. Fault movements formed dilational jogs manifested by NW-SE-trending en-echelon tension gash veins. Four main alteration zones are identified: (a) phyllic, (b) argillic, (c) sub-propylitic and (d) weak subpropylitic. Ore minerals consist of native gold, electrum, native silver, pyrite, chalcopyrite, sphalerite, galena, arsenopyrite, cubanite, marcasite, covellite and tennantite, which are commonly associated with

${ }^{*}$ Corresponding author: A. IDRUS, Department of Geological Engineering, Gadjah Mada University. Jl. Grafika 2 Yogyakarta, Indonesia. E-mail: arifidrus@ugm.ac.id
\end{abstract}

argillic alteration. Vein structures such as massive, swarm and low angle veins, stockwork and veins dispersed in diatreme breccia are present. Normal banded, cockade, crustiform, bladed carbonates as well as, comb and saccharoidal features are the typical vein textures. It is noteworthy that the veins are basically composed of carbonate with minor quartz at gold grades of up to $83 \mathrm{~g} / \mathrm{t} \mathrm{Au}$. Based on the vein structures and textures, four stages of ore mineralization were developed consisting of (a) early stage (fluidized breccia and quartz vein), (b) middle stage (carbonate-base metal), (c) late stage (late carbonate), and supergene stage. Gold mineralization originated mainly during middle and late stages, particularly in association with cockade, crustiform, bladed carbonate-base metal veins. Based on those various features, the LS epithermal deposit in the study area is categorized as carbonate-base metalgold mineralization type.

Keywords: Geology, Ore mineralization, Hydrothermal alteration, LS epithermal, Paningkaban area, Indonesia.

\section{Introduction}

Fifteen magmatic arcs are identified in Indonesia which have a total extent in excess 
of $15.000 \mathrm{~km}^{2}$. However $98 \%$ of the country's precious (gold, silver) and base metals (particularly copper) are derived exclusively from six arcs of mid-Tertiary or younger age (Carlile and Mitchell, 1994). These six major Neogene mineralized magmatic arcs include the SundaBanda, Central Kalimantan, Sulawesi-East Minandao, Halmahera and Central Papuan fold and thrust belt. The Sunda-Banda arc is the longest of the magmatic arcs in Indonesia. It extends nearly 4,000 km from northern Sumatra through Sumbawa (Sunda arc) and onwards through Flores to its terminus in the Banda Islands (Banda arc). One of the most mineralized segments of the Sunda-Banda magmatic arc is the southern part of Java Island. Our research location, Paningkaban, is one of the gold-mineralized regions situated in Central Java, $165 \mathrm{~km}$ west of Yogyakarta (Figure 1).

Several primary gold and base metal deposits were discovered along the Sunda-Banda magmatic arc, for instance, Kapur-Natas in North Sumatera (Idrus et al., 2007), Gunung Pongkor in West Java (Warmada, 2003), Selogiri in Wonogiri (Imai et al., 2007) and Batu Hijau in Sumbawa (Garwin, 2000). All gold-base metal deposits described above are hosted by volcanic rocks. Gold exploration activities in Indonesia are recently not only focused on volcanic/magmatic belt, but also starting to shift along metamorphic and sedimentary terrains. Primary gold mineralization occurring in association with metamorphic rocks are, for instance, Awak Mas in South Sulawesi (Querubin and Walters, 2011) and Gunung Butak in Buru Island, Mollucas (Idrus et al., 2014). However, no advanced studies have been conducted for hypogene gold deposits, particularly LS epithermal gold vein types hosted by sedimentary rocks such as in the Paningkaban area.

\section{Research methods}

This study is conducted in four stages including literature, fieldwork, laboratory work, data processing and interpretation. Fieldwork includes mapping of surface geology, alteration and ore mineralization as well as sampling of representative rock types, altered rocks and gold-bearing veins. Laboratory work includes slab and vein textural and structural analysis, mineralogy (petrography, ore microscopy and $X$-ray diffraction) and ore/mineral chemistry analyses of a total of 77 samples. Mineralogical analysis was conducted at Department of Geological Engineering, Gadjah Mada University, ore chemistry was done at AAS laboratory, Intertek Jakarta, and gold chemistry was analysed by EPMA at IML-RWTH Aachen University.

\section{Results and Discussion}

\section{Geology}

The study area is underlain by a series of sedimentary units, which from oldest to youngest are interlayered sandstone and siltstone, tuff, calcareous sandstone, and limestone (Figure 2). The interlayered sandstone and siltstone unit is the host rock of LS epithermal gold mineralization in the study area. This unit is a member of the Miocene Halang formation. The feldsparrich rock unit is weakly to intensely altered from subpropylitic to argillic alteration styles. The age of the volcano-sedimentary rock unit is Late Miocene (Djuri et al., 1996). Younger rock units are not mineralized and not altered. Pre- and syn-mineralization structures such as extension joints, normal-sinitral fault and sinitral fault controlled the gold mineralization and alteration. Fault movements formed dilational jogs manifested by N-S, NE-SW and NW-SEtrending en-echelon tension gash veins (Figure 3).

\section{Hydrothermal alteration}

Four main alteration zones are identified including: (a) phyllic alteration typified by sericite-quartz-pyrite \pm carbonate \pm chlorite, (b) argillic alteration presented by illite-smectiteillite/smectite-carbonate-quartz-sericitedickite \pm chlorite, (c) sub-propylitic alteration characterized by chlorite-chlorite/smectitesmectite-carbonate \pm quartz \pm zeolite, and (d) weak sub-propylitic alteration composed of chlorite-smectite \pm carbonate mineral assemblages, respectively. Ore mineralization is 


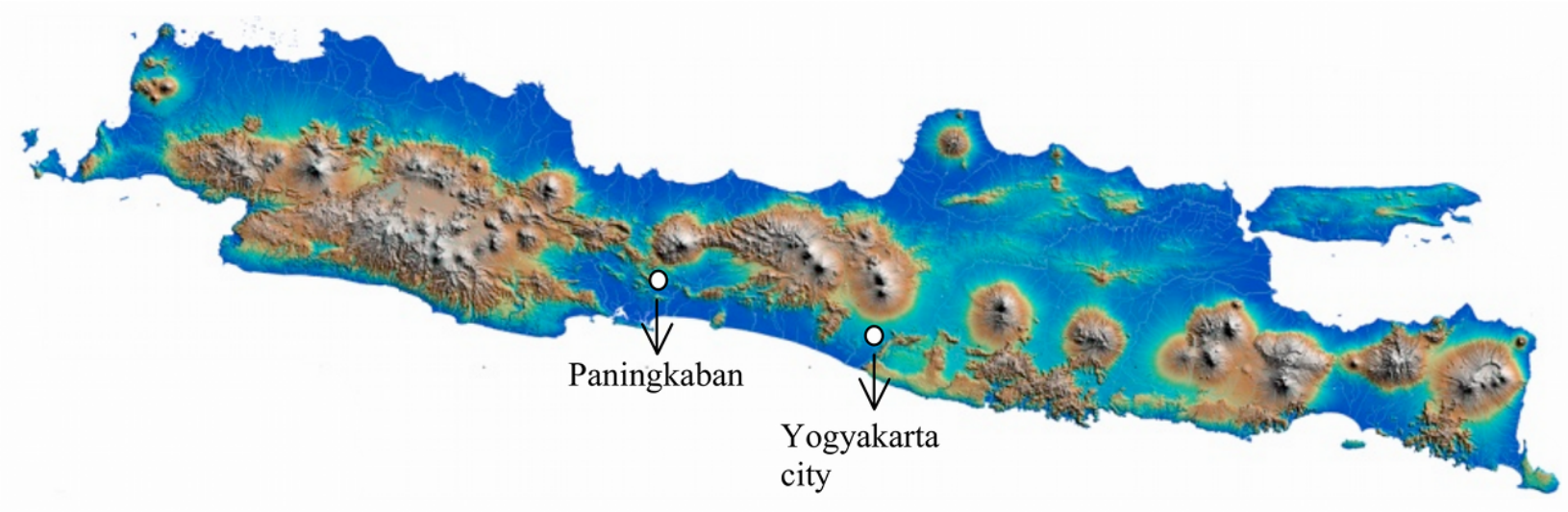

Figure 1: Research location (Paningkaban area) plotted on the SRTM (Shuttle Radar Topography Mission) map of Java Island.

closely associated with argillic and weak subpropylitic alteration (Figure 4).

\section{Ore mineralization}

Vein structures such as massive, swarm and low angle veins, stockworks and diatreme breccia-hosted veins are present. Normal banded, cockade, crustiform, bladed carbonate, comb and saccharoidal are the typical open space filling textures of the LS epithermal veins. It is noteworthy that the veins are composed of carbonate with minor quartz and adularia and gold grades ranging from 0.09 to $83 \mathrm{~g} / \mathrm{t} \mathrm{Au}(8$ vein samples). Electrum chemistry shows 73.9 wt. $\% \mathrm{Au}$ and $23.5 \mathrm{wt} . \% \mathrm{Ag}$, respectively.

Based on the vein structures and textures, four stages of ore mineralization in the study area were developed consisting of: (a) early stage (fluidized breccia and quartz vein), (b) middle stage (carbonate-base metal), (c) late stage (late carbonate), and supergene stage (Table 1). Gold mineralization chiefly occurred during Middle and Late stages particularly in association with cockade, crustiform, bladed carbonate-base metal veins (Table 1 and Figure 5). Less abundant electrum is also identified within banded quartz veins from the early stage.

Precious metals identified consist of native gold, electrum and native silver (Figure 5), sulphides consist of pyrite, chalcopyrite, sphalerite, galena, arsenopyrite, cubanite, marcasite, covellite and tennantite. Gold-bearing veins are
Table 1: Ore and gangue mineral paragenetic sequences of LS epithermal gold mineralization at the Paningkaban area.

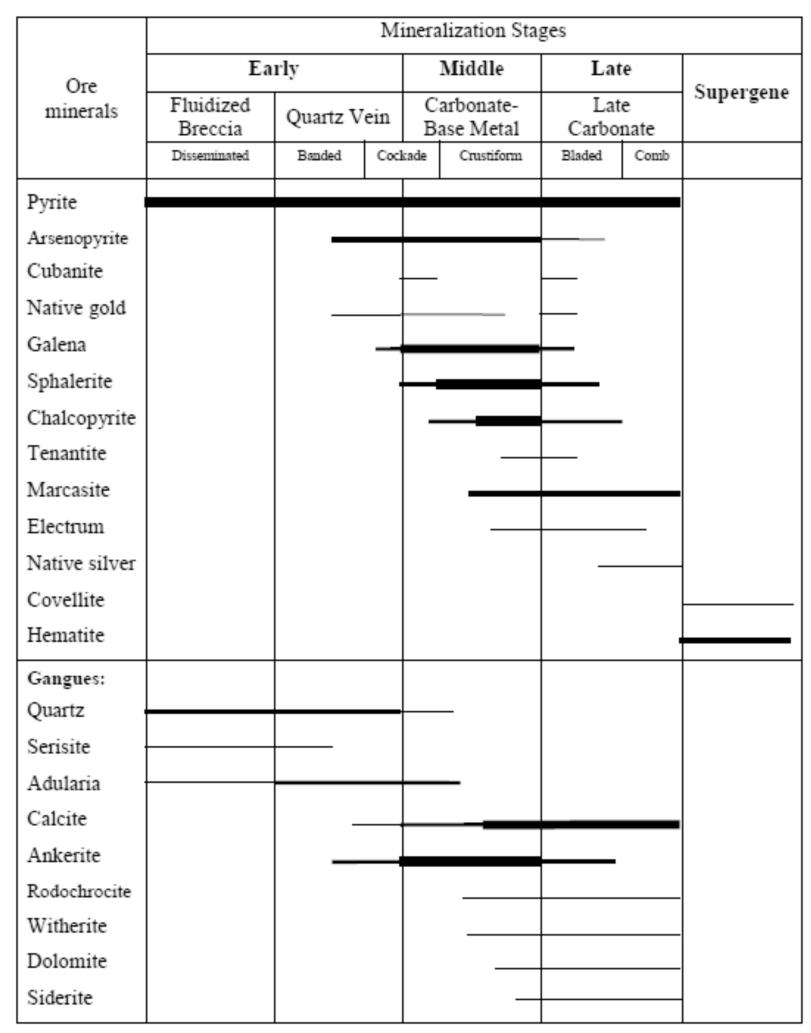

$\underline{\text { Less abundant }}$ Moderate $\quad$ Abundant 


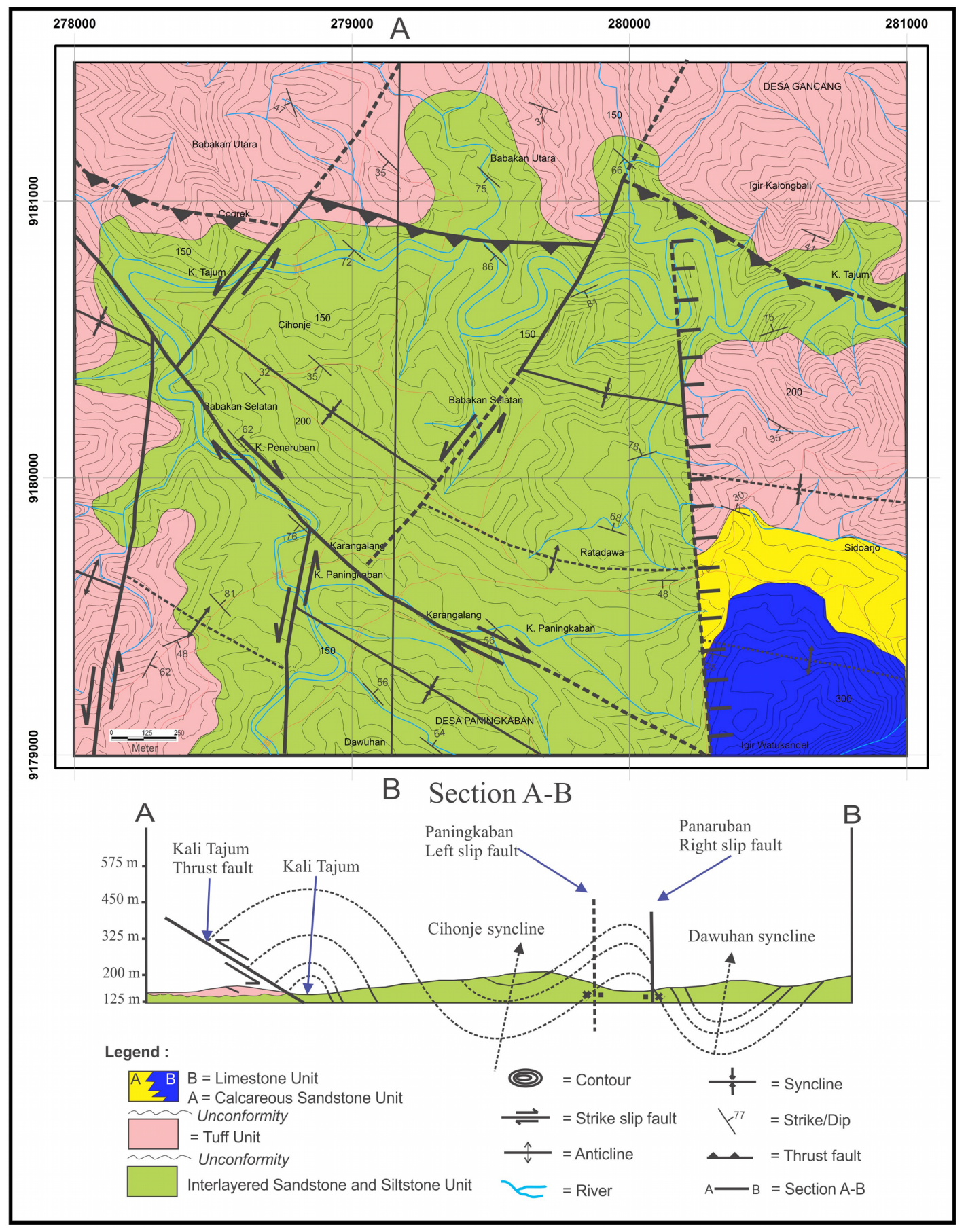

Figure 2: Geological map and cross section of the Paningkaban area. 

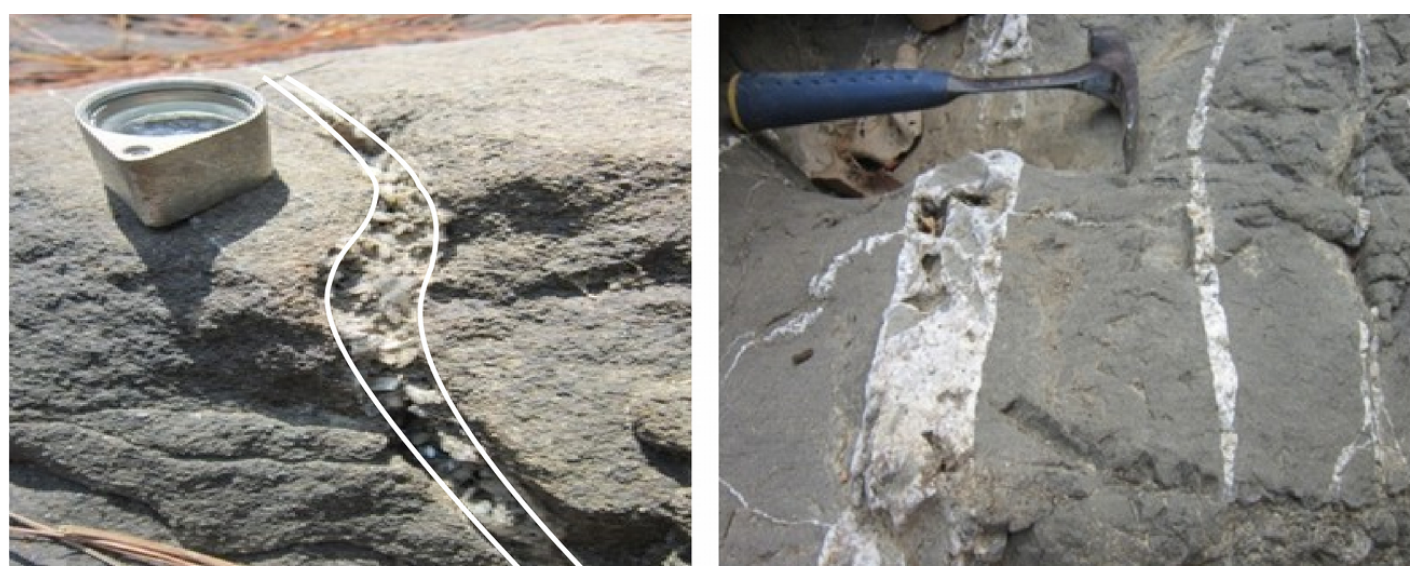

Figure 3: NW-SE-trending en-echelon tension gash veins hosted by sandstone of Miocene Halang formation.

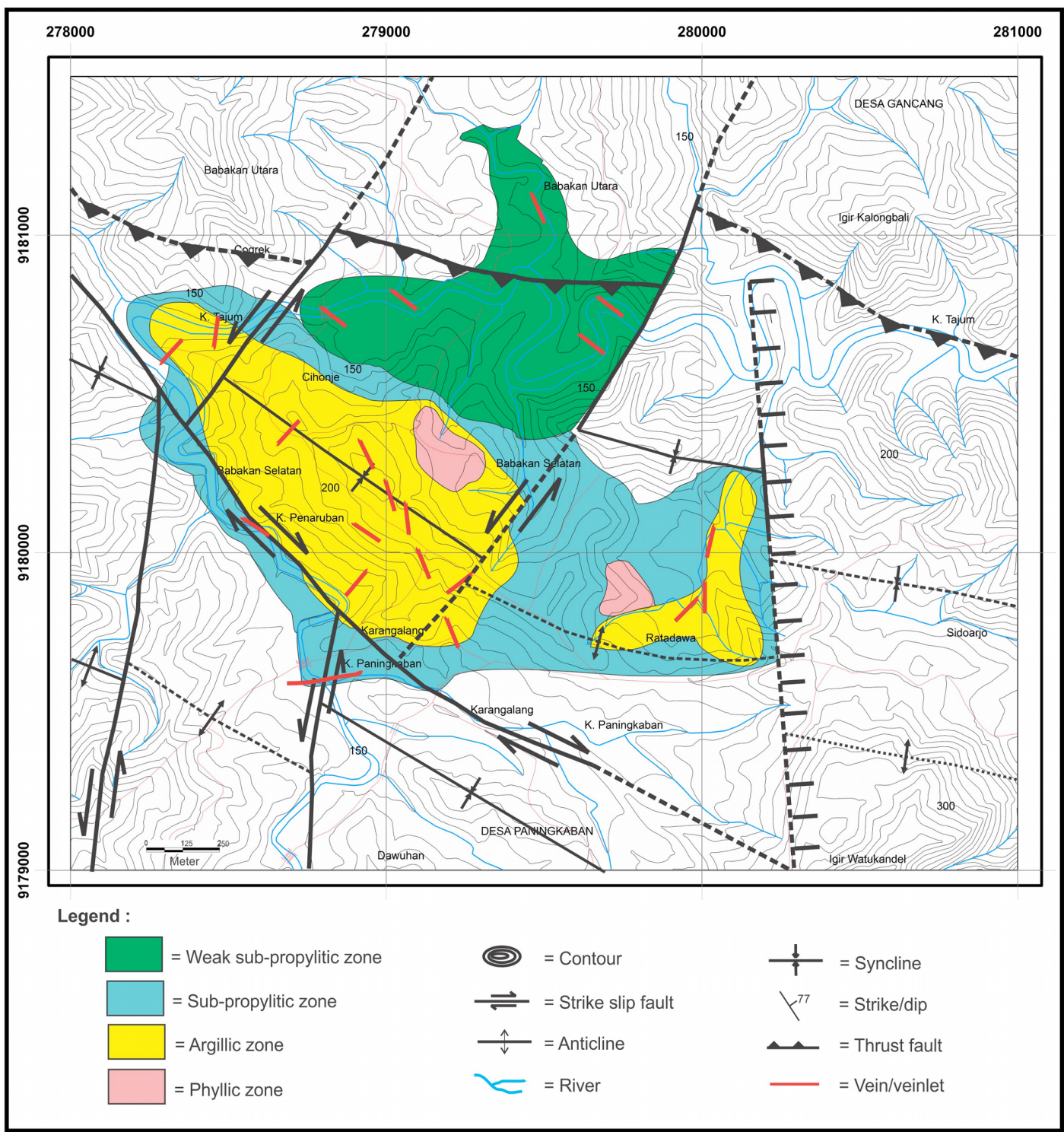

Figure 4: Hydrothermal alteration map of the Paningkaban area. 

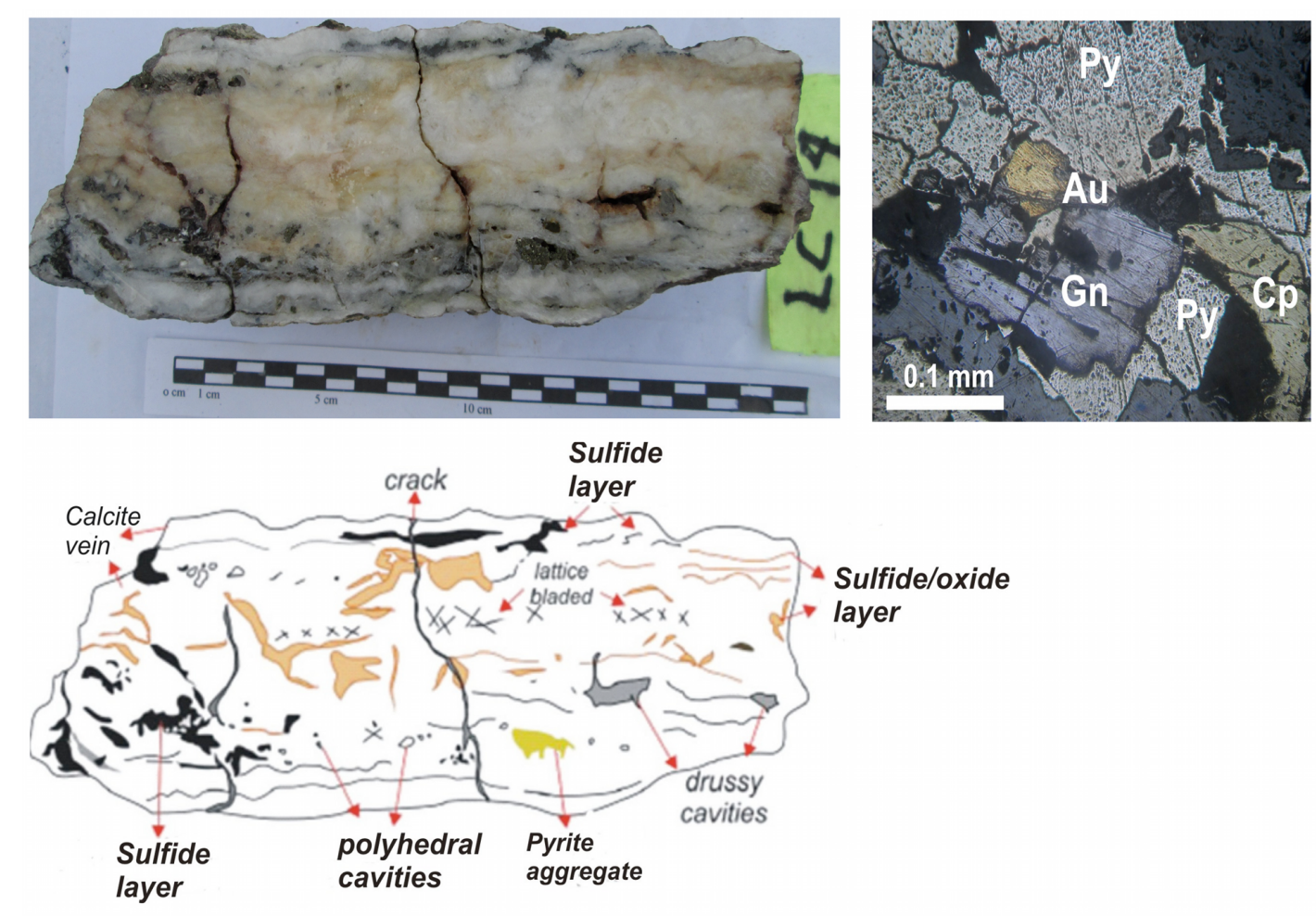

Figure 5: Photograph of a crustiform-bladed carbonate vein (top left) with related sketch (bottom), photomicrograph of ore sample showing the presence of native gold $(\mathrm{Au})$ and base metal sulphides in the vein (top right).

commonly associated with argillic and weak sub-propylitic alteration types (Figure 4). It is obvious that the epithermal veins are predominantly composed of gold and base metal sulphides in association with carbonate (calcite and ankerite) and minor quartz as gangue minerals.

\section{Implication for exploration}

The Paningkaban LS epithermal gold veins hosted by interlayered sandstone-siltstone unit of the Miocene Halang formation is the only known gold deposit, which is mined by smallscale miners in the region. Lithologic control and extensional structural deformation forming dilational jogs are the important geological factors for the formation of gold mineralized $\mathrm{N}-\mathrm{S}, \mathrm{NE}-\mathrm{SW}$ and NW-SE-trending en-echelon tension gash veins. A careful study on the deposit geology, hydrothermal alteration, and ore characterization is crucial for an economic evaluation of the deposit since resulted maps and ore deposit characteristics are needed for designing an effective exploration program and a positive cost-benefit result of this gold deposit type as a new primary gold resources in Indonesia.

\section{Conclusion}

Two important geological factors controlling the formation of the LS epithermal gold veins at Paningkaban area. These are the specific lithological make up (i.e., interlayered sandstone and siltstone) as well as pre- and synmineralization extensional and transtensional structures. Transtensional fault movements caused dilational jogs manifested by N-S, NESW and NW-SE-trending gold mineralized enechelon tension gash veins.

On the basis of hydrothermal alteration types, ore and gangue mineral associations and characteristics, structures and textures of epithermal veins, and by comparison with existing models (cf. Corbett, 2004), it suggested 
that the gold deposit occurring in the study area is a carbonate-base metal gold mineralization sub-type of a LS epithermal system. The Tertiary sedimentary rocks that host this gold mineralization could be a new target for gold exploration in the future in Indonesia, particularly in the regions that are of similar geologic evolution and structural setting.

\section{Acknowledgements}

This study was funded by DIKTI International Research Collaboration and Scientific Publication (KLN) research grant 2015/2016 awarded to the first author. Fieldwork was partly supported by Blacksmith project in collaboration with GEUS (Geological Survey of Denmark and Greenland). EPMA analysis was done by Sutarto and Roman Klinghardt at IML RWTH Aachen University. Their support is thankfully appreciated.

\section{References}

Carlile, J.C. and Mitchell, A.H.G (1994) Magmatic arcs and associated gold and copper mineralisation in Indonesia: in van Leeuwen, T.M., Hedenquist, J.W., James, L.P., and Dow, J.A.S., eds., Mineral Deposits of Indonesia, Discoveries of the Past 25 Years: Journal of Geochemical Exploration, v. 50, pp. 91-142.

Corbett, G.J. (2004) Epithermal and porphyry gold - geological models. Proceedings PACRIM Congress 2004, Adelaide. pp. 15-23.

Djuri, M., Samodra, H., Amin T.C. and Gafoer, S. (1996) Geological Map Sheet of Purwokerto-Tegal, scale 1:100.000. Centre of Geological Research and Development, Bandung.

Garwin, S.L. (2000) The setting, geometry and timing of intrusion-related hydrothermal systems in the vicinity of the Batu Hijau porphyry copper-gold deposit, Sumbawa, Indonesia: Unpublished Ph.D. Thesis, University of Western Australia, Perth, 320 p.

Idrus, A., Pulungan, B.A.A. and Titisari, A.D. (2007) Geology, hydrothermal alteration and mineralization of the Kapur-Natas epithermal low sulphidation, South Tapanuli district, North Sumatra - Indonesia, Prosiding PIT IAGI, Bali, November 2007, pp. 1 - 11.

Idrus, A., Prihatmoko, S., Hartono, H.G., Fadlin, Ernowo, Franklin, Moetamar and Setiawan, I. (2014) Some key features and possible origin of the metamorphic rockhosted gold mineralization in Buru island, Indonesia, Indonesian Journal on Geoscience, 1: 9-19.

Imai, A., Shinomiya, J., Soe, M.T., Setijadji, L.D., Watanabe, K., Yoshikawa, R. and Warmada, IW. (2007) Porphyry-type mineralization at Selogiri area, Wonogiri regency, Central Java, Indonesia. Resource Geology 57: 130-140.

Querubin, C.D., and Walters, S. (2011) Geology and Mineralization of Awak Mas: A Sedimentary Hosted Gold Deposit, South Sulawesi, Indonesia, Proceedings of The Sulawesi Mineral Seminar, Manado 28-29 November 2011, pp. 211-229.

Warmada, IW. (2003) Ore mineralogy and geochemistry of the Pongkor epithermal goldsilver deposit, Indonesia, Dissertation. Papierflieger, Clausthal-Zellerfeld, $107 \mathrm{p}$. 